\title{
Morphology and Ecology of Bivalve Molluscs from Admiralty Bay, King George Island, Antarctica
}

\author{
Theresinha M. Absher* and Angela R. Feijó \\ Centro de Estudos do Mar, Universidade Federal do Paraná, Av Beira Mar s/n, CEP 83255-000 Pontal do Sul, \\ PR, Brazil
}

\begin{abstract}
Bivalve species were collected from shallow coastal areas of King George Island (Martel, Mackellar and Ezcurra Inlets of Admiralty Bay). Twenty one species belonging to 16 genera and 12 families were identified and their morphometric and morphological shell characteristics were described. Three main characteristics were found to be common to the majority of the bivalve species sampled: 1) thin fragile shells; 2) small size of individuals (76\%), and 3 ) the lack of true cardinal teeth (72\%). Comparison of calcium data from a tropical estuary and a subantarctic coastal shallow area suggested that the calcium in the sea water was not a constraint to shell building but shell thickness could be an adaptation to the efficiency of energy partitioning. Small individual size and the lack of true cardinal teeth are discussed in relation to a high deposition environment and widespread mud bottoms.
\end{abstract}

Key words: Bivalve species, Antarctic bivalves, King George Island, Antarctica

\section{INTRODUCTION}

The occurrence and identification of molluscs in various areas of Antarctica have been reported by several authors, e.g. Thiele (1912), SootRyen (1951), Powell (1951), Dell (1964), Nicol (1966), Arnaud (1973) by Dell (1990), Hain (1990), Sieg \& Wägele (1990), Branch et al (1991), Rauschert (1991) and Arnaud \& Hain (1992). Peculiarities of the Antarctic molluscs, mainly size and shell characteristics were discussed by Nicol $(1964 ; 1967)$ and Arnaud (1974), but no considerations were made about the energetic cost of calcium deposition in shell. The knowledge of invertebrate fauna of Admiralty Bay has been mainly due to the joint effort of Brazilian and Polish researchers based at the Antarctic Brazilian Research Station

\section{MATERIALS AND METHODS}

Study area: King George Island is located in the South Shetland archipelago. Admiralty Bay is the largest bay of King George Island and opens into the Bransfield Strait to the south and southeast, having the tip of the Antarctica
"Comandante. Ferraz" and the Polish Antarctic Station "Henryk Arctowski", respectively (Jazdzewski et al, 1986; Arnaud et al, 1986; Wägele \& Brito, 1990). However, these studies lack taxonomic and morphological information on bivalve species. The scope of this work is under the SCAR CS-EASIZ programme to improve the knowledge of the Antarctic coastal and shelf ecosystem. Antarctic researchers have concentrated their studies in deep waters. However, sheltered bays and inlets are very particular ecosystem with few studies in Antarctica. In this paper, we describe the bivalve molluscs of Martel, Mackellar and Ezcurra Inlets in Admiralty Bay of King George Island (South Shetlands) with an aim to provide a basis for morphological and ecological studies of bivalve species from Admiralty Bay and the South Shetland Islands.

Peninsula on the far side of the Bransfield Strait (Fig.1).

The physical and chemical settings of Admiralty Bay were described by Polish researchers (Rakusa-Suszczewski, 1993). Martel, Mackellar and Ezcurra Inlets are

\footnotetext{
* Author for correspondence
} 
innermost parts of the Admiralty Bay. The combined surface area of the three inlets is 58,27 $\mathrm{km}^{2}$ which accounts for almost half of the total area of the bay. The bottom of shallow areas of the three inlets $(0-15 \mathrm{~m})$ are covered by patches of rocky substrata..Water transparency changes considerably throughout the year from 2-3m during summer to $32 \mathrm{~m}$ in winter in the $20-100 \mathrm{~m}$ layer. (Pecherzewski, 1980). Water temperature varies annually from $3,1^{\circ} \mathrm{C}$ to $-1,9^{\circ} \mathrm{C}$ (RakusaSuszczewski, 1993). Salinity is stable over the bay. During summer, salinity is low in surface waters $(32,9-34,0 \%)$, which increases with depth $(34,5 \%)$
Sampling: Qualitative sampling using various gears (trawl-net, dredge, Van Veen grab) was conducted. Sampling area at Admiralty Bay included the shallow zone down to $80 \mathrm{~m}$ of Martel, Mackellar,and Ezcurra Inlets.(Fig.1). Sorting of the sampling collection were done at the Brazilian Station "Comandante Ferraz" at mesh size of $1 \mathrm{~mm}$. All samples were preserved in formaldehyde (4\%), neutralised with sodium borate for transportation to the Malacology Laboratory (Centro de Estudos do MarUFPR).The systematic arrangement followed the description of Vokes (1980) and Vaught (1989). The size of the species referred in the descriptions are of the largest specimen collected.
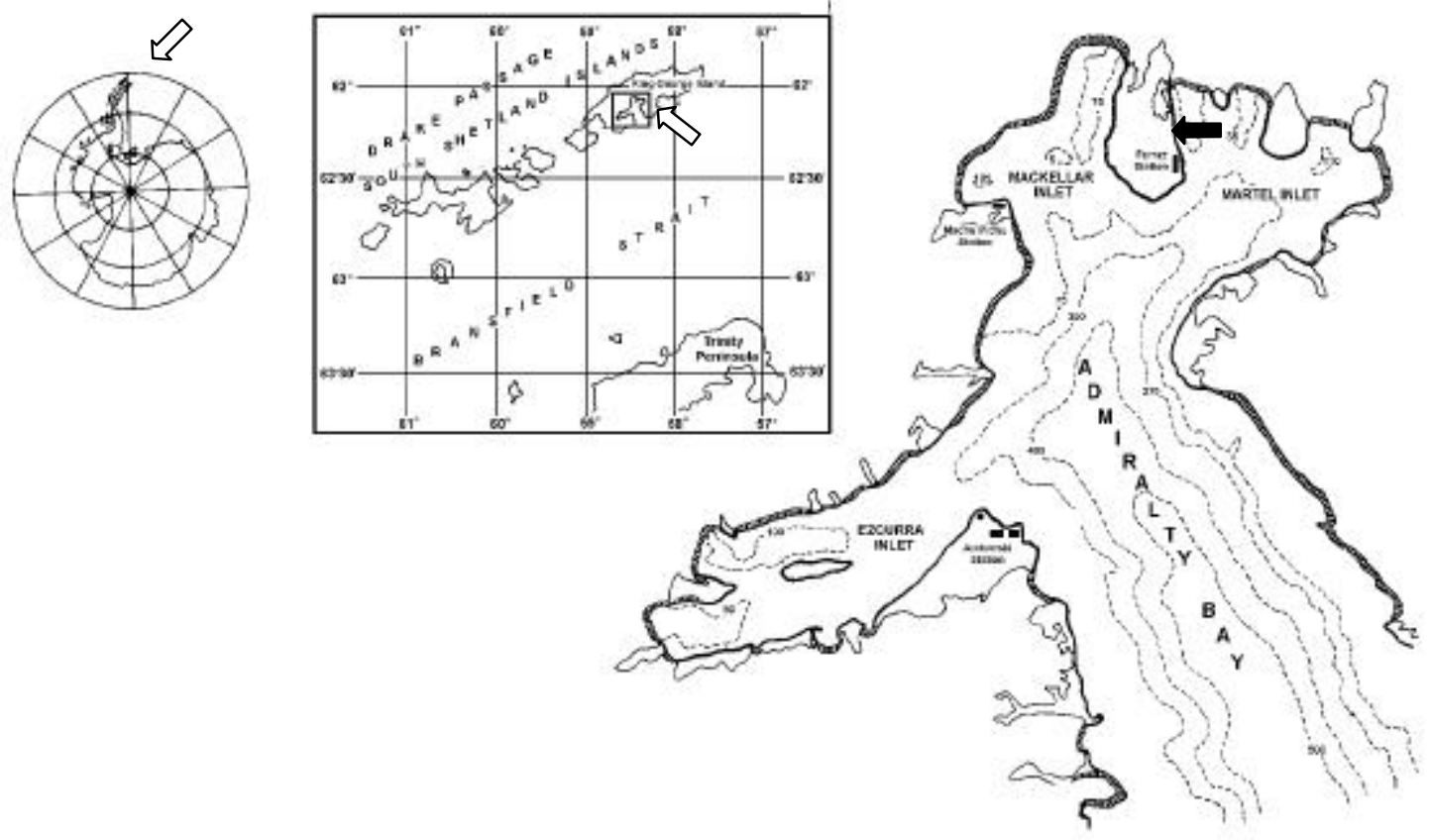

Fig. 1: Admiralty Bay, King George Island - Martel, Makellar and Ezcurra Inlets. ' Brazilian Antarctic Research Station "Comandante Ferraz".

\section{RESULTS}

Twenty one Bivalvia species were identified, which belonged to 16 genera and 12 families.
Figs 2-5 show shell morphology. Diagnostic characters of each species are individually described. 

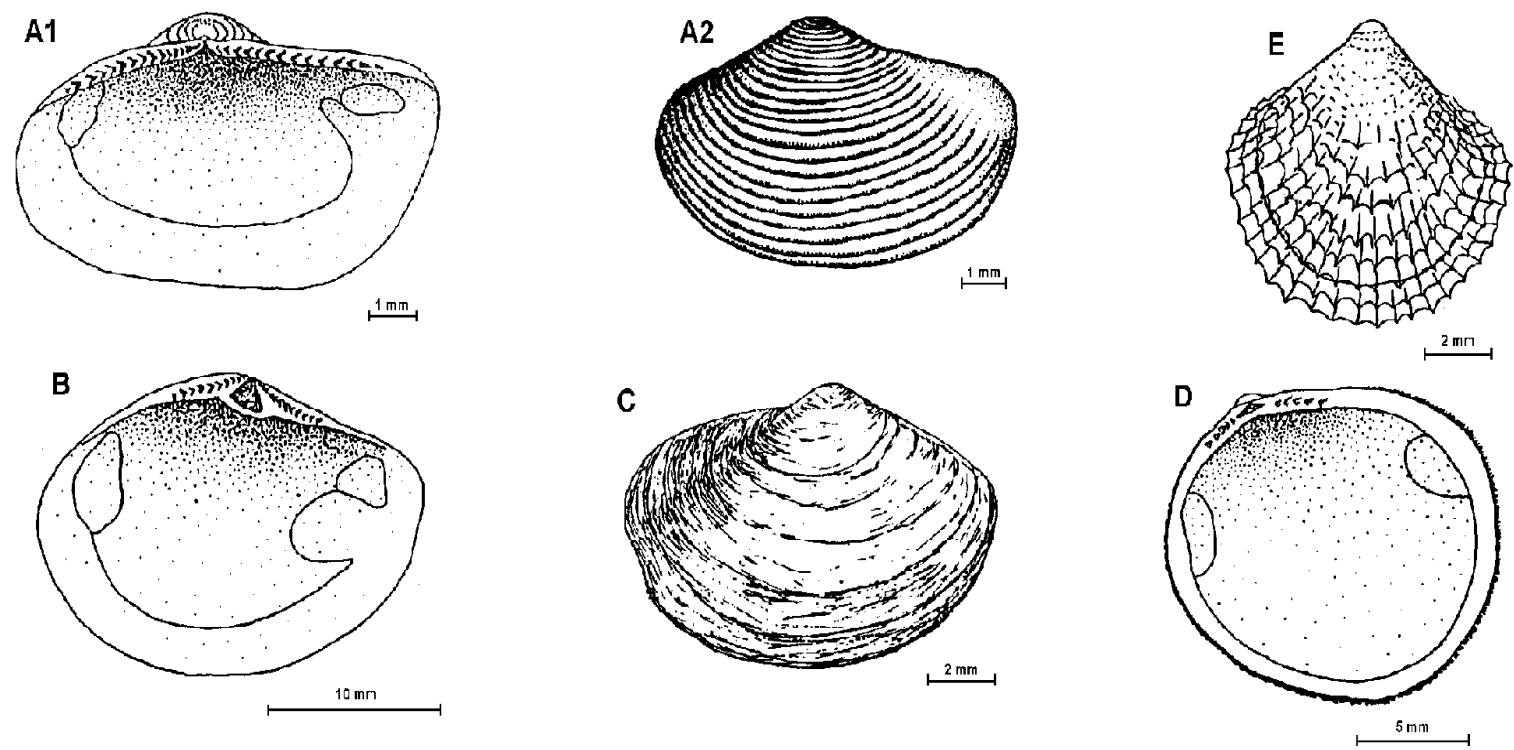

Fig. 2: $\mathrm{A}_{1}, \mathrm{~A}_{2}$ - Nuculana inaequisculpta; B - Yoldia eightsi; C - Yoldiella sabrina; D - Limopsis lilliei; E Philobrya sublaevis.

\section{Subclass PALEOTAXODONTA Korobkov, 1954}

Family NUCULANIDAE Adams \& Adams, 1858

Nuculana inaequisculpta (Lamy, 1906) Fig. 2$\mathrm{A}_{1}$ and $\mathrm{A}_{2}$ (5.3 x 8.9mm-height $\mathrm{x}$ length). Shell small, elongate, yellowish white, shining, thin and fragile. Equivalve, slightly inequilateral. Shell ornamentation of concentric elevated ridges, regularly spaced in the middle part of the shell but less visible at the anterior and posterior ends. Beaks set out just off centre of dorsal line of shell. Hinge taxodont. Adductor muscle scars subequal. Pallial line forming a very small indentation (not a true pallial sinus).

Yoldia eightsi (Couthouy, 1839) Fig. 2-B (14.8 x 22.6mm). Medium size shell, compressed, equivalve, inequilateral. Shell fragile, chalky and covered by a shine brownish periostracum. Valves gape anteriorly and posteriorly. Anterior end rounded and posterior end fan shaped. Usually eroded beaks, prodissoconch not visible. Sculpture of growth lines and fine radial striae. Internal ligament located in a triangular pit. Ten taxodont teeth on each side of the ligament. Pallial sinus deep and round. Adductor muscles scars subequal in size, posterior one larger.

Yoldiella sabrina (Hedley, 1916) Fig. 2-C .(7.5 x $12.0 \mathrm{~mm})$. Shell small, white, compressed, thin and fragile. Equivalve and inequilateral. Outline oblong covered by a thin, shine yellow, periostracum. Prodissoconch visible in adult shells. Sculpture of growth lines only. Umbones central. Ligament internal in a triangular pit. Taxodont hinge, 13 teeth on each side of the ligament. Adductor muscle scars subequal, the posterior being round and larger than the elongate anterior. Foot large.

\section{Subclass PTERIOMORPHIA Beurlen, 1944}

\section{Family LIMOPSIDAE Dall, 1895}

\section{Limopsis lilliei Smith, 1915 Fig. 2-D}

$(20,0 \times 21.6 \mathrm{~mm})$. Shell medium size, white under the periostracum. Equivalve, almost equilateral. Shell suborbicular, length slightly greater than height. Brown bristle periostracum in concentric rows superimposing radial striae, giving a reticulate appearance to the valve surface and overlapping the ventral margin of the shell. Hinge line short gently curved, strong taxodont teeth, 4 anterior and 5 posterior. 

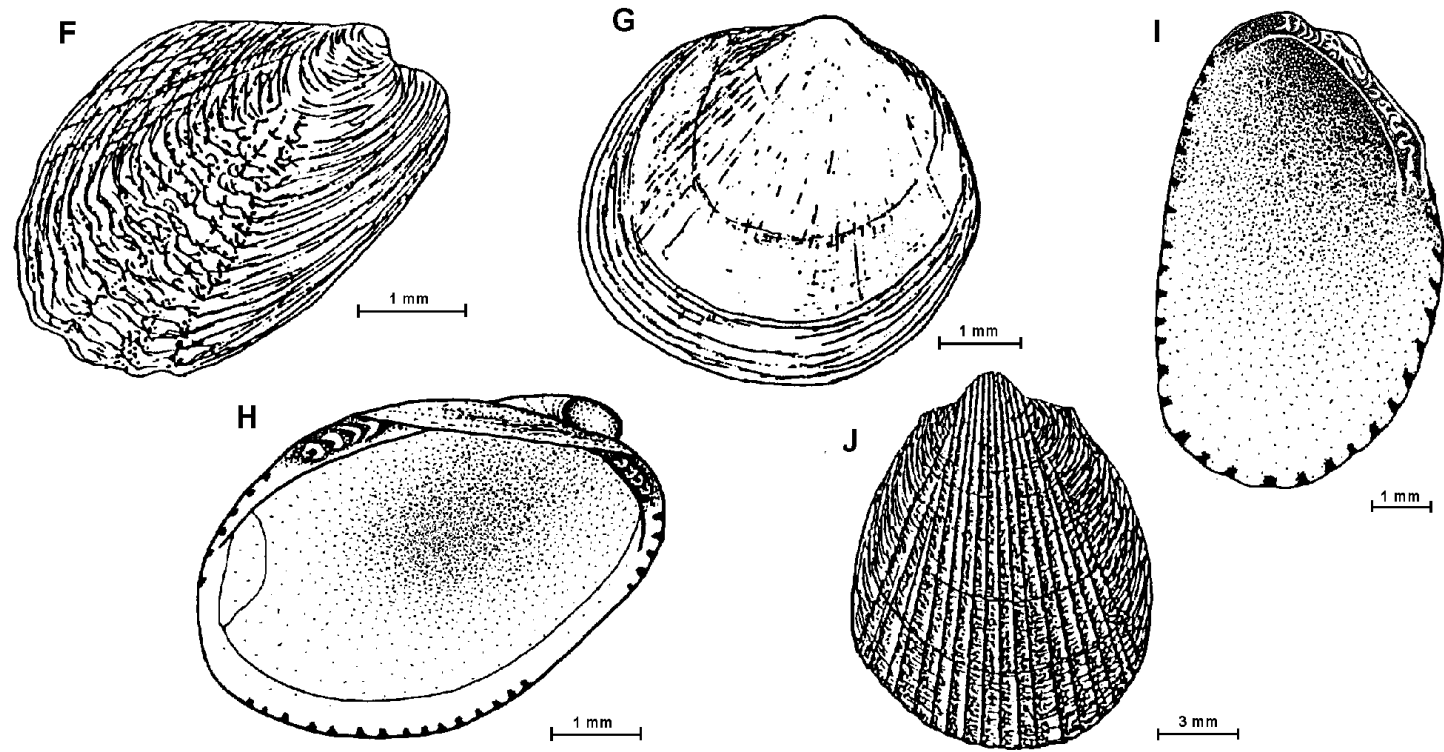

Fig. 3: F - Philobrya wandelensis; G - Adacnarca nitens; H - Lissarca miliaris; I - Lissarca notorcadensis; J Limatula pygmaea.

Internal ligament in a shallow pit. Deep umbonal cavity. Pallial line entire, no pallial sinus. Adductor muscles scars subequal in size

\section{Family PHILOBRYIDAE Bernard, 1897}

Philobrya sublaevis (Pelseneer, 1903) Fig. 2-E $(7.0 \times 6.8 \mathrm{~mm}$ or $9.0 \times 9.0 \mathrm{~mm}$ with periostracum). Shell small, white with a porcellaneous shine under the preriostracum, thin and fragile. Height and length subequal. Equivalve, slightly inequilateral.. Dorsal margins straight, ventral, anterior and posterior margins rounded. Umbones high and round. Ligament in a groove on the posterior dorsal margin.. Prominent, transparent periostracum disposed in concentric rows and with radial plicae, overlapping the anterior, posterior and ventral margins. Edentulous. Lunular area present, but not a true lunula. Byssus present. Radial striae visible on the inside of shell. Posterior internal margin crenulated

\section{Philobrya wandelensis Lamy, 1906 Fig. 3-F}

$(4.2 \times 2.8 \mathrm{~mm})$. Shell small, white, thin and fragile. Equivalve, inequilateral. Shell higher an extensive ligamental area. Byssus present. Pimples at the internal margins of valves, except in a small portion of the anterior and posterior margins. Concentric striae over the whole valve. than long. Periostracum light brown slightly overlapping the ventral margin. Surface of valves ornamented with fine concentric lines and 6 prominent radial ridges at the central part of valves. The axis from umbo to the posterior ventral margin very oblique. Beaks orthogyrate. Hinge without teeth. Ligament internal in a triangular pit.

Adacnarca nitens Pelseneer, 1903 Fig. 3-G

$(4.2 \times 4.0 \mathrm{~mm})$. Shell small, white, thin and fragile. Equivalve, inequilateral. Shell outline subcircular. Periostracum very thin, brown. No ornamentation on surface of valves, except for growth rings and faint radial striae, more evident from the inner side of shell. Valve margins denticulate. Hinge with vertical striae separated by ligament. Larval shell noticeable in adults.

Lissarca miliaris (Philippi, 1845) Fig. 3-H $(4.0 \times 5.6 \times 3.3 \mathrm{~mm})$. Shell small, dark brown, thin and fragile. Equivalve, inequilateral beaks near anterior margin. Flaky yellow periostracum evident at margins of valves. Interior of shells of the same color as exterior. Straight dorsal margin. Hinge teeth taxodont, 4 at each side of Some individuals with faint radial striae more evident near the ventral margin.

Lissarca notorcadensis Melvill and Standen, 1907 Fig. 3-I 
$(7.0 \times 6.0 \mathrm{~mm})$. Shell small white, thin and fragile. Equivalve, strongly inequilateral.. Hinge area narrow, ligament in a pit. Taxodont teeth. Seven laminar teeth at a ligament side and 5 bigger teeth on the other side. Bissus present. The hinge axis to the posterior ventral margin has a strong slope. Pimples around the internal margins of the valves but lacking at the byssus.

Family LIMIDAE Rafinesque, 1815

\section{Limatula pygmaea (Philippi, 1845) Fig. 3-J}

$(14.1 \times 11.2 \times 11 \mathrm{~mm}$; ratio length to height $=$ 0.79). Shell small, white yellowish, with 24 radial striae over fine concentric treads, on the central part of shell surface, laterals with concentric treads only. Equivalve and slightly inequilateral. Auricles on each side of the umbones. Beaks orthogyrate, usually eroded. Ligament in a central buttress. Hinge without teeth. Deep umbonal cavity. Four radial striae visible on the inside of shell. Monomyarians, posterior adductor muscle scar only.

Subclass HETERODONTA Neumayr, 1884

Family THYASIRIDAE Dall, 1901

Thyasira falklandica (E.A.Smith, 1885) Fig. 4-K (18.2 x $17.9 \mathrm{~mm})$. Shell small, chalky, almost round. Equivalved, slightly inequilateral. Beaks small and prosogyrate. Periostracum thin, membranaceous and brownish. Shell ornamentation of fine, irregular, concentric lines. A sulcus from the umbones to the ventral area is present at the posterior end of the valves. Ligament in a dorsal groove, opisthodetic. Hinge without teeth. Interior margins of shell smooth. Pallial line without a sinus. Adductor muscle scar unequal, anterior elongate, posterior smaller and round.
Family MONTACUTIDAE Clark, 1855

Mysella miniuscula (Pfeffer, 1886) Fig. 4-L $(2.8 \times 3.6 \mathrm{~mm})$. Shell minute, thin and almost triangular. Periostracum dark brown. Equivalved, slightly inequilateral. Shell surface with minute concentric striae. Angle from the umbo between anterior and posterior margins of about $120^{\circ}$. Internal margins of shell smoth. Pallial sinus lacking. Adductor muscle scar subequal, one more elongate than the other. One valve with no cardinal teeth the other with 2 cardinal teeth. Ligament internal..

\section{Mysella charcoti (Lamy, 1906) Fig. 4-M}

$(3.2 \times 3.8 \mathrm{~mm})$.Shell minute, thin, longer than height. Periostracum orange-coloured. Equivalve, strongly inequilateral. Shell surface with minute concentric striae. Dorsal margin almost parallel to ventral margin. Angle from the umbo between anterior and posterior margins of about $90^{\circ}$. Internal margins of shell smooth. Pallial sinus lacking. Adductor muscle scar subequal, one more elongate than the other. Hinge of one valve without teeth, the other with 2 cardinal teeth. Ligament internal in a triangular pit.

\section{Family CYAMIIDAE Sars, 1878}

Cyamiomactra laminifera (Lamy, 1906) Fig.4-N $(7.0 \times 10 \mathrm{~mm})$. Shell small, white, oblong, thin and fragile. Equivalve, inequilateral. covered by a shine and thin yellowish periostracum. Anterior end of valves rounded and posterior truncated by a radial ridge that runs from the umbo to the posterior margin. Shell ornamentation of fine concentric growth lines. Internal ligament located in an oblique groove. Two divergent cardinal teeth in the right valve and 3 in the left valve, the middle one bifid. Pallial line without a sinus. Adductor muscle scars elongate. Internal margins of valves smooth. 

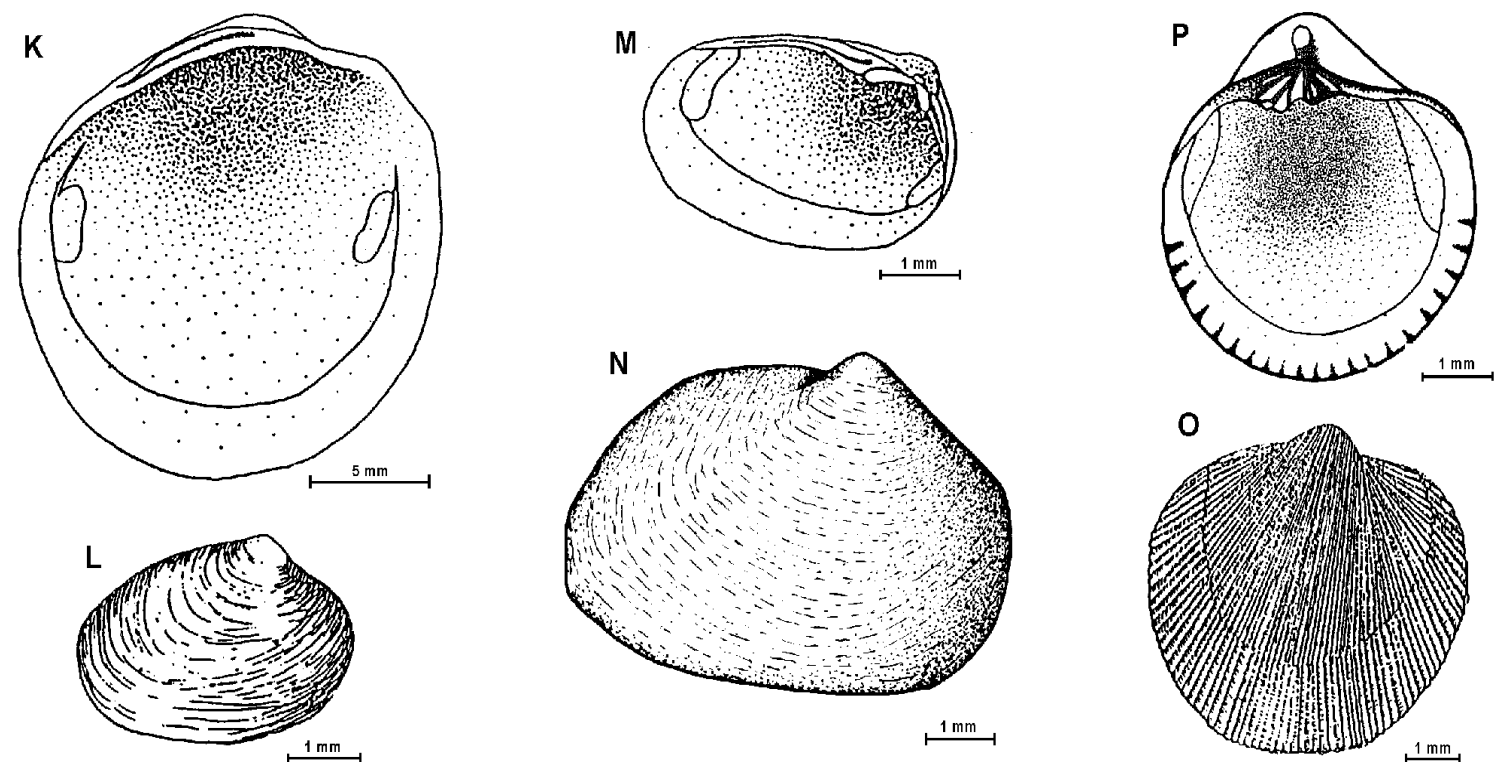

Fig. 4: K - Thyasira falklandica; L - Mysella miniuscula; $\mathrm{M}$ - Mysella charcoti; $\mathrm{N}$ - Cyamiomactra laminifera; $\mathrm{O}$ - Cyamiocardium denticulatum; P - Cyamiocardium crassilabrum.

\section{Family PERRIERINIDAE Soot-Ryen, 1959}

\section{Cyamiocardium denticulatum (E.A.Smith,1907)}

\section{Fig. 4-O}

$(4.8 \times 4.9 \mathrm{~mm})$. Shell small, delicate, white, outline oblong oval. Equivalved, slightly inequilateral, posterior side slightly longer than anterior. Beaks orthogyrate. Larval shell preserved in adults. Periostracum thin and yellowish. Fine radial striae and very fine concentric lines present on shell surface. Concentric growth lines visible. Ligament in a pit posterior to the beaks. Hinge with 2 laminar cardinals teeth in each valve. Internal margins of valves denticulate. Pallial sinus lacking. Adductor muscles scar unequal, one elongate and the other smaller and round.

Cyamiocardium crassilabrum Dell, 1964 Fig.4$\mathrm{P}(4.0 \times 5.0 \mathrm{~mm})$. Shell small, white, outline almost circular. Equivalve, slightly inequilateral, inflated. Beaks orthogyrate. Larval shell preserved in adults, usually protruding form the beaks,.periostracum thin and greyish. Shell surface with radial lines crossed by fine concentric lines. Concentric growth lines visible. Ligament internal. Two cardinal teeth in each valve, one laminar the other large. Internal margins of valves denticulate. Pallial sinus lacking. Adductor muscle scars equal and elongate. Similar to the former species but with an overall coarser aspect and stronger marginal crenulations.

Family CARDITIDAE Fleming, 1820

Cyclocardia astartoides (von Martens, 1878)

Fig. 5-Q

$(25.0 \times 28.8 \mathrm{~mm})$. Shell medium size, strong, covered with a brown periostracum. Equivalved, inequilateral, oblong (longer than height). Radial ribs and growth lines present at shell surface. Beaks prosogyrate. Ligament external. Hinge with 2 cardinal teeth in the left valve and 3 in the right valve. Adductor muscle scars subequal, anterior one more elongate. Pallial line entire. Ventral inner margins crenulated. Radial lines visible from the inside of lower half of shell.

\section{Family THRACIIDAE Stoliczka, 1871}

Thracia meridionalis E.A.Smith, 1885 Fig. 5-R $(23.0 \times 30.3 \times 13.0 \mathrm{~mm})$. Shell medium size, yellowish white, thin and fragile. Inequilateral, slightly inequivalved, right valves overlaps left valve at ventral margin right umbo higher than left. Shell shape squarish, posterior margin 


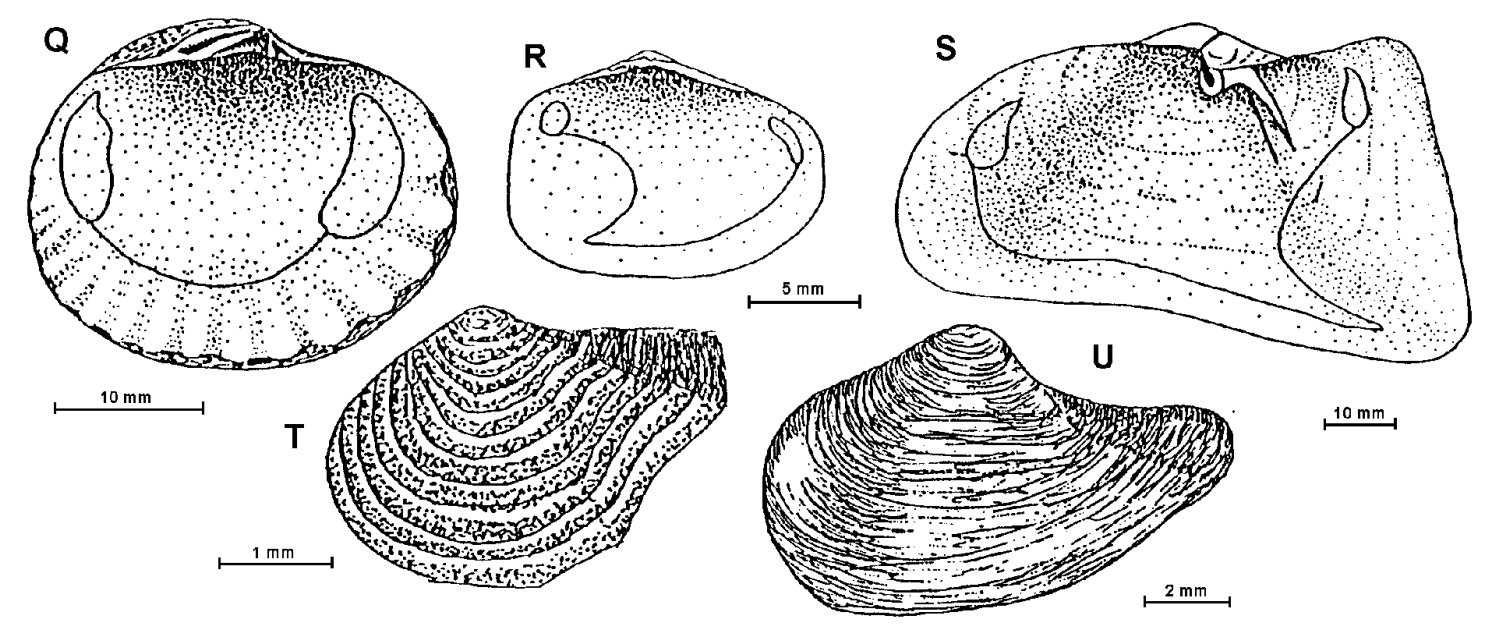

Fig. 5: Q - Cyclocardia astartoides; R - Thracia meridionalis; S - Laternula elliptica; T - Cuspidaria kerguelenensis; $\mathrm{U}$ - Cuspidaria infelix.

truncated. Irregular spaced concentric lines. Valves gape at the posterior end. A ridge may be present at the posterior end of valves, running from umbones to the posterior margin. Beaks orthogyrate. Larval conch eroded. Hinge without teeth. Ligament external in a lithodesma. Pallial sinus shallow, squarish. Adductor muscle scars unequal in size and shape, elongated anterior and. smaller rounded posterior.

\section{Family LATERNULIDAE Hedley, 1918}

Laternula elliptica (King and Broderip, 1831) Fig. 5-S

$(41.2 \times 80.0 \mathrm{~mm})$. Shell large, white, thin and fragile. Slightly inequivalved, left valve overlaps right valve. Inequilateral, elongate, gaping at both ends, the posterior gape being larger. A ridge runs from the umbones to the postero-ventral margin. Beaks small opisthogyrate. Larval shell persistent in adults. Ligament internal in a chondrophore . Hinge without teeth. Shell internal surface nacreous, internal margins smooth. Pallial sinus large. Adductor muscle scars small, subequal. Prominent siphon not entirely retractile.

\section{Family CUSPIDARIIDAE Dall,1886}

Cuspidaria kerguelenensis Smith, 1885 Fig. 5-T $(2.5 \times 3.5 \mathrm{~mm})$. Shell small, shine, white, thin and fragile. Equivalve, strongly inequilateral, elongate. Rostrum protruding, truncated at the end. Raised concentric ridges, regularly spaced, not visible at the superior part of the rostrum. Beaks orthogyrate. Periostracum present only on the rostrum. A ridge from the umbo to the posterior end sets out the rostrum and a radial groove delimits the shell surface. Ligament internal in a chondrophore

Cuspidaria infelix Thiele, 1912 Fig. 5-U

$(7.1 \times 11.5 \mathrm{~mm})$. Shell small, dull white, elongate, thin and fragile. Slightly inequivalve, strongly inequilateral. Short rostrum not set out by a ridge, tapering from the shell surface, gapping at the end. Beaks orthogyrate. Shell ornamentation of fine irregularly spaced concentric treads. Hinge without teeth. Ligament internal in a chondrophore.

\section{DISCUSSION}

Seventeen species sampled here were similar to those listed by Arnaud et.al (1986) for Admiralty Bay. Seventeen species were also in common with Rauschert's (1991) data on bivalves from Maxwell Bay of King George Island-Admiralty Bay. However, Yoldiella sabrina, Cyamiocardium crassilabrum and Cuspidaria kerguelenensis were not reported by these authors. This is the first occurence registered for those three species in the area.

Three main characteristics were common for the majority of the bivalve species found in Admiralty Bay: 1) thin fragile shells; 2) small 
size of individuals (76\%), and 3) the lack of true cardinal teeth $(72 \%)$. The plasticity of bivalve shells frequently reflects similared life style leading to parallel or convergent evolution (Seed, 1980). Analysis of convergence adaptation provides an insight on the significance of environmental forces leading to morphological changes. The mechanism of shell building basically involves an uptake of calcium from the external medium and transportation through the mantle epithelium for deposition in an organic matrix (Wilbur \& Owen, 1964). Two main requirements are necessary for this process to occur - the presence of enough calcium in the medium and expenditure of energy for the process to take place. Fragile shells of Antarctic invertebrates have been attributed to lack of calcium in the waters. Graus (1974) attributed the increase in efficiency of shells in utilising calcium carbonate in a latitudinal gradient towards the equator to the availability of calcium carbonate in the external medium. Calcium is a major element of ocean water; at $35 \%$ of salinity there is $412 \mathrm{mg} / \mathrm{kg}$ of calcium in ocean water but in certain conditions, it may not have a conservative behaviour in relation to salinity (Riley \& Chester, 1971). Antarctic environmental regimes are remarkable stable when compared with tropical regions. In a tropical estuary, while temperatures are more on the elevated plateau, calcium has a conservative behaviour in relation to salinity. At Paranaguá Bay (Southern Brazil), the annual variation in bottom water temperature is from 19 to $29^{\circ} \mathrm{C}$ while salinity goes from 23 to $30 \%$ and calcium carbonate concentration varies from 249 to 325 $\mathrm{mg} / \mathrm{kg}$ (Absher, 1989). Estuarine molluscs have less availability of calcium carbonate as a shell building material. Nevertheless Crassostrea oysters, characterised by strong shells, were able to grow thick and strong shells from recruitment (length $0.5 \mathrm{~mm}$ ) to $50 \mathrm{~mm}$ in 6 months (Absher, 1989). Sea water at Signy Island (60 43'S-45 $38^{\prime} \mathrm{W}$ ) was observed to contain a mean of 395.6 $\mathrm{mg} / \mathrm{l}$ of calcium at a temperature of $+0,71^{\circ} \mathrm{C}$ and salinity of 33,9\%o (Nolan, 1991) and at Martel Inlet (Admiralty Bay) at 15 to $60 \mathrm{~m}$ depth, $.303 .75 \mathrm{mg} / \mathrm{kg}$ of calcium at a temperature of $+1^{\circ} \mathrm{C}$ and salinity of $34.05 \%$ (R.Montone, personal communication). Comparing this data with the above mentioned for a tropical estuary, there seemed to be no deficiency in calcium in the cold water. On the other hand, the whole physiology of Antarctic invertebrates pointed to an economy of energy leading to low basal metabolic rates, decreased reproductive output and slow growth (Clarke, 1979). The temperature effect and seasonality of food would lead to a reduction on energy intake with an increase in efficiency (Clarke, 1983). The energy budget must be partitioned among the various individual metabolic needs. Research has shown that shell building required a great part of the energy for growth in molluscs. 26\% of the total body energy has been estimated to be required for shell deposition. (Griffiths \& King, 1979). Tropical molluscs have no constraints on calcium metabolism due to temperature and the need for economy of energy. Calcium carbonate deposition in low temperature regimes may be the result of the efficiency in utilising the available resources (amount of calcium carbonate and energy required for shell building), thus being dependent on the combined effect between the need for economy of energy due to adaptative metabolic rates to cold water and the availability of calcium in the medium due to solubility particularities. Thin shells may be the best solution for the constraints imposed by environmental characteristics. In turn, thin and fragile shells lead to an adaptation strategy for shallow burrowers to increase buoyancy and avoid clogging that is a small size. In order to keep a large surface/volume ratio and to maximise support from the substratum shell must be small (Stanley, 1970). The high sedimentation rate in a sheltered environment further favours the development of small size individuals. Most of the bivalve species are suspension feeders that must cope with the amount of inorganic suspension during summer and corresponding deposition on the bottom layers. Secchi disc visibility at the three inlets during summer varies from 0.8 to $4.7 \mathrm{~m}$. with the average of $2.9 \mathrm{~m}$ (pers. obs.), reflecting a trend in Antarctic sheltered bays (Rakusa-Suszczewski, 1993). Infaunal burrowers in mud bottoms must be able to a rapid burrowing with a strong feet (the case of Yoldia eightsi) or be able to deep burrowing as Laternula elliptica which is able to burrow as deep as $40 \mathrm{~cm}$ (Wägele \& Brito, 1990). The 
presence of few species with fully developed heterodont hinge is an indication of the widespread mud bottoms around Antarctica. Taxodont teeth was present in $29 \%$ of the species and $43 \%$ lacked teeth

\section{ACKNOWLEDGEMENTS}

This work was supported by a grant from CNPQ/PROANTAR-Brasilia-Brazil. We thank Dr John Taylor for the help with the bibliography, Dr Andrew Clarke for critically reviewing a draft of the manuscript, to $\mathrm{Dr}$ Patrick Arnaud for verifying the identifications and to the British Antarctic Survey for the facilities provided.

\section{RESUMO}

Espécies de bivalves foram coletadas na região costeira rasa da Ilha Rei George (Enseadas Martel, Mackellar e Ezcurra da Baía do Almirantado). Vinte e uma espécies pertencentes a 16 gêneros e 12 famílias foram identificadas e as caractrísticas morfológicas e morfométricas das conchas descritas. Destacaram-se 3 características principais comuns à maioria das espécies: 1) conchas finas e frágeis; 2) pequeno tamanho dos indivíduos (76\%), e 3) a ausência de dentes cardinais (72\%). A comparação entre os dados de cálcio de um estuário tropical e uma região rasa costeira subantártica sugeriu que os valores de cálcio na água do mar não seriam uma restrição à formação das conchas, mas a espessura das conchas poderia ser uma adaptação à eficiência na distribuição da energia. Discute-se a ausência de dentes cardinais e pequeno tamanho dos indivíduos em ralação a um ambiente de alta deposição e abundância de fundos lodosos.

\section{REFERENCES}

Absher, T. M. (1989). Populações naturais de ostras do gênero Crassostrea do litoral do Paraná: desenvolvimento larval, recrutamento e crescimento. $\mathrm{PhD}$ Thesis. São Paulo University, Oceanographic Institute, São Paulo, Brazil
Arnaud, P. M.. (1973). .Invertébrés marins des XII ${ }^{\text {eme }}$ et $\mathrm{XV}^{\text {eme }}$ Expéditions Antarctiques Française en Terre Adélie.13 Polyplacophores, Scaphopodes, et Pelecypodes. Tethys, 5:549-560

Arnaud, P. M.. (1974). Contribution à la bionomie marine benthique des régions antarctiques et subantarctiques. Tethys, 6:465-656

Arnaud, P. M. \& Hain, S. (1992). Quantitative distribution of the shelf and slope molluscan fauna (Gastropoda, Bivalvia) of the eastern Weddell Sea (Antarctica). Polar Biol., 12:103-109

Arnaud, P. M.; Jazdzewski, K.; Presler, P. \& Sicinski, J. (1986). Preliminary survey of benthic invertebrates collected by Pollish Antarctic Expeditions in Admiralty Bay (King George Island, South Shetland Islands Antarctica). Pol. Polar Res., 7:7-24,

Branch, M. L.; Arnaud, P. M.; Cantera, J. \& Gianokouras, D. (1991). The benthic Mollusca and Brachiopoda of subantarctic Marion and Prince Edward Islands. S. Afr. J. Antarctic Res., 21(1):45-64

Clarke, A. (1979). On living in cold water: kstrategies in Antarctic benthos. Mar. Biol., 55:111-119

Clarke, A. (1983). Life in cold water: the physiological ecology of polar marine ectotherms. Oceanogr. Mar. Biol. Ann. Rev., 21:341-453

Dell, K. (1964). Antarctic and subantarctic Mollusca: Amphineura, Scaphopoda and Bivalvia. Discovery Rep., 33:93-250

Dell, R. K. (1990). Antarctic Mollusca.with special reference to the fauna of the Ross Sea. Bull. Royal Soc. New Zealand, 27:1-311

Graus, R. R. (1974). Latitudinal trends in the shell characteristics of marine gastropods Lethaia, 7:303-314

Griffiths, C. L. \& King, J. A. (1979). Energy expended on growth and gonad output in the ribbed mussel Aulacomya ater. Mar. Biol., 53:217-222

Hain, S. (1990). Die beschalten benthischen Mollusken (Gastropoda und Bivalvia) des Weddelmeeres Antarktis. Ber. Polarforsch., 70:1-184.

Jazdzewski, K.; Jurasz, W.; Kittel, W.; Presler, E.; Presler, P. \& Sicinski, J. (1986). Abundance and biomass estimates of the benthic fauna in Admiralty Bay, King 
George Island, South Shetland. Polar Biol., 6:5-16

Nicol, D. (1964). An essay on size of marine Pelecypodes. J. Paleont., 38:968-974

Nicol, D. (1966). Descriptive ecology and geographic distribution of some Antarctic pelecypodes. Bull. Amer. Paleontol., 51:1102

Nicol, D. (1967). Some characteristics of coldwater marine Pelecypods. J. Paleont., 41:1330-1340

Nolan, C. P. (1991). Environmental aspects of growth in the Antarctic molluscs Nacella concinna (Patellidae) and Yoldia eightsi (Nuculanidae) at Signy Island, South Orkney Islands. Ph D Thesis, The University of Hull, United Kingdom

Pecherzewski, K. (1980). Distribution and quantity of suspended matter in Admiralty Bay (King George Island, South Shetland Islands). Pol. Polar Res., 1:75-82

Powell, A. W. B. (1951). Antarctic and Subantarctic Mollusca: Pelecypoda and Gastropoda. Discovery Rep., 26:47-196, pl $\mathrm{V}-\mathrm{X}$

Rakusa-Suszczewski, S. (ed) (1993). The Maritime Antarctic coastal ecosystem of Admiralty Bay. Warsaw: Dept. Antarctic Biol., Polish Academy of Sciences

Rauschert, M. (1991). Faunistic investigations in the Benthal of King George Island. Ber. Polarforsch., 76:1-75

Riley, J. P. \& Chester, R. (1971). Introduction to Marine Chemistry. Academic Press, London

Seed, R. (1980). Shell growth and form in the Bivalvia. In: Skeletal growth of aquatic organisms: biological records of environmental change, eds D. C. Rhoads \& R. A. Lutz, Plenum Press, New York, pp. 2367

Sieg, J. \& Wägele, J. W. (eds) (1990). Fauna der Antarktis. Verlag Paul Parey, Berlin

Soot-Ryen, T. (1951). Antarctic Pelecypodes. Sci. Res. Norw. Ant. Exp. 1927-1928, 32:1-42

Stanley, S. M. (1970). Relation of shell form to life habits of the Bivalvia (Mollusca).: The Geological Society of America Inc. Memoir, Colorado

Thiele, J. (1912). Die antarktischen Schnecken und Muscheln. Dtsch. Südpol-Exp. 19011903, 13:183-285,

Vaught, K. C. (1989). A classification of the living Mollusca: American Malacological Incorporation, Melbourne

Vokes, H. E. 1980. Genera of the Bivalvia revised. Paleontol. Res. Inst., New York

Wägele, J. W. \& Brito, T. A. S. 1990. Die sublitorale Fauna der maritimen Antarktis.Erste Unterwasserbeobachtungen in der Admiralitätsbucht. Natur und Museum, 120:269-282

Wilbur, K. M. \& Owen, G. 1964. Growth. In: Physiology of Mollusca, eds K. M. Wilbur \& C. M. Yonge. Academic Press, New York, v.1, pp. 211-242.

Received: June 21, 1998; Revised: July 30, 1998; Accepted: November 12, 1998. 